Crime, Histoire \& Sociétés / Crime, History \& Societies

Vol. 21, n² | 2017

L'histoire de la criminalité et de la justice pénale : propositions de recherche pour le $21^{\mathrm{e}}$ siècle

\title{
Spatialized Communication: Future Research Perspectives on Urban Youth Violence and on Terrorism
}

Klaus Weinhauer

\section{CpenEdition}

\section{Journals}

Electronic version

URL: http://journals.openedition.org/chs/2002

DOI: $10.4000 /$ chs.2002

ISSN: 1663-4837

Publisher

Librairie Droz

Printed version

Date of publication: 31 December 2017

Number of pages: $309-319$

ISSN: $1422-0857$

\section{Electronic reference}

Klaus Weinhauer, "Spatialized Communication: Future Research Perspectives on Urban Youth Violence and on Terrorism", Crime, Histoire \& Sociétés / Crime, History \& Societies [Online], Vol. 21, n² I

2017, Online since 19 July 2020, connection on 14 January 2021. URL: http://

journals.openedition.org/chs/2002 ; DOI: https://doi.org/10.4000/chs.2002 


\title{
Spatialized Communication: Future Research Perspectives on Urban Youth Violence and on Terrorism
}

\author{
Klaus Weinhaver
}

$\mathrm{V}$ iolence is one of the biggest threats to urban societies. Since the advent of mass urban societies during the nineteenth century, towns and cities have been at the center of heated debates about urban decay, vice, crime and violence. Insecurity and urban conflicts even shaped early social science definitions of cities. In a pioneering characterisation Louis Wirth defined cities "as a relatively large, dense, and permanent settlement of socially heterogeneous individuals", but added that the social structure of the city "tends toward the acceptance of instability and insecurity in the world at large as a norm"1. The French sociologist and philosopher Henri Lefèbvre further stressed (in 1970) that the urban environment was a "place of conflict and confrontation, a unity of contradictions [...] where conflicts are expressed"2.

Violence in urban settings was often seen as a byproduct of rapid social change, as a consequence of social and cultural uprooting or as an individual pathology. Since the 1990s, a revision of these somewhat abstract and technical interpretations has occurred, and the act of violence itself has come under scrutiny ${ }^{3}$. Authors have increasingly choosen to focus on physical violence, which has been studied through a close look at the interactions between victims, perpetrators and bystanders. Research has demonstrated that everybody can act violently at any time, although Randall Collins has convincingly demonstrated that it is not easy to overcome the emotionally coded confrontational tension and fear barrier" ${ }^{4}$. However, this emergent "actororiented" close reading of violent interactions still needs tools which help to integrate practices of physical violence into broader social and cultural processes. The key words which point in this direction are: communication and space.

Violence is a pattern of communication, which can evoke related communication (Anschlusskommunikation). Especially since the emergence of modern, mass media societies in the nineteenth century, the communicative potentials of violence have to be taken seriously. Seen this way, it becomes obvious that violence is not senseless and has no inbuilt tendency always to escalate. Rather, there are many opportunities to stop or to deescalate violent communications. As I have indicated above, violent

\footnotetext{
$1 \quad$ Wirth (1938, p.8 and 16).

2 Lefèbvre (1970/2003, p.175).

3 For an overview, see Weinhauer and Ellerbrock (2013).

4 Collins (2008).
}

Crime, Histoire \& Sociétés / Crime, History \& Societies 2017, vol. 21, n², pp. 309-319. 
communication is performed in a triadic setting (involving at least one perpetrator and at least one victim, and often bystanders too, which can include the media). Violence is also about order. While for victims the experience of violence may reorder time perceptions and bodily experiences, for groups of perpetrators it may also serve to create order, which may enable them to act effectively. Moreover, the experience and practices of violence may have long term effects, as they affect individual and collective memories.

To analyze violent communication requires an understanding of spatial practices. Henri Lefèbvre's concept of the formation of relational spaces encapsulates the importance of this thesis ${ }^{5}$. Space is not a given container but shaped by three interrelated levels, by a triad of practices: By the interaction of everyday spatial practices (1, perceived space), with representations of space (2, conceptualized space of planners, social engineers, etc.) and with representational spaces (3, a lived space, with its symbols, images, etc., which its users seek to appropriate and to change). Following this interaction, urban violence is a spatialized social and cultural practice influenced by individual and collective imaginations, imaginaries, memories, and by stories told about urban settings ${ }^{6}$. All this is by no means confined by nation state borders but transnationally and translocally interlinked with other spatial practices taking place in tight urban networks of communication. Put concisely, violence is less an anomaly than a communication- and space-based social practice which can create order and meaning(s).

If we try to put such an understanding of violence into research practice it is important to study which individual and which groups participate in acts of violence and in which urban settings such practices occur. In what follows, this will be accomplished via a case study of youth violence in Chicago in 1919. It is also important, however, to counter the (seemingly) omnipresent impression that urban violence only follows one pattern: that is, that it always increases in scale and severity. Hence, a second case study will consider urban terrorism in Northern Ireland and in Germany since the 1970s, as instances where political violence was eventually overcome and subdued. Both case studies underline that the urban is shaped by conflicts and that these conflicts are not only staged in the city but that these conflicts can also be about the city?

\section{URBAN YOUTH VIOLENCE: GANGS AS SOCIAL MOVEMENTS}

"Violence by young people is one of the most visible forms of violence in society", the World Health Organization postulated in $2002^{8}$. In 2005 an US army publication claimed that youth violence by gangs in Central America marked a

See Lefèbvre (1974/1991, p.38-40); Wood (2007).

6 Imaginaries are more stable than individual imaginations and are shaped by (contested) collective social and cultural images, understandings and perceptions; see Buitrago et al. (2016).

Castells (2016).

$8 \quad$ Krug et al. (2002, p.25). 
"new urban insurgency". Labeling acts of violence as youth violence, however, is analytically highly problematic. One problem is to clearly discern who falls under the label "youth". The second problem is the label "gangs". Influenced by US-American research, the gang perspective was since the 1920s exported on a global scale. The results of US-research were often uncritically applied to settings in other regions like Latin America, Africa but also Europe ${ }^{10}$.

Jack Katz has brilliantly criticized the pitfalls of the dominant stream of USgang research. The usual assumption is: where gangs exist there is more crime ${ }^{11}$. Many studies focus on gangs as windows into a world of disorder and decay, instead of studying the everyday life of gangs. Some important causal questions are not often addressed within the literature: Do individuals become more criminal when they enter a gang? Do gangs increase the level of criminal violence in a setting? What accounts for their emergence, spread and evolution toward more or less more violence? Katz raises two important claims. First, it may well be that "violence causes gangs much more powerfully than gangs cause violence" ${ }^{12}$. That is, that one act of violence may make groups into gangs. Second, gangs reduce violence since they are so intimidating that people may hesitate to start conflicts with them. Gangs may also serve to discipline violence-prone members via a ruthlessly enforced internal code of behavior. The activities of gangs are not, of course, solely limited to the second half of the twentieth century.

What follows is a case study of Chicago in 1919, where racialized urban violence was employed extensively by juveniles, which takes a closer look at how gangs might be more adequately conceptualized and at how these entities are involved in collective action. Globally, the years immediately following the First World War saw frequent collective actions which were often violent. As I have demonstrated elsewhere, the Great War had mobilized the respective societies and brought tremendous changes (restructuring of industry, food rationing, military mobilization) to working-class neighborhoods ${ }^{13}$. Translocal migration was an important war-induced mobilization. This migration not only intensified competition on the labor market but also led to competition over housing. All these war-induced challenges led to a mobilization of the local resources of the working-classes in order to cope with these situations. In a process which I call "localization" members of local working-class communities developed an intense spatial awareness which in turn activated existing (or even spawned the formation of) locally rooted self-help social movements ${ }^{14}$. These movements often competed with established working-class organizations but also used the network resources of the latter.

$9 \quad$ Rodgers and Jones (2009, p.2.). While the UN claims, that youth are people aged between 15 and 24 some countries often due to legal regulations use a wider age frame.

10 On the uncritical transfer of drug related fears to Europe, see Weinhauer (2013).

$11 \quad$ Katz $(2004$, p.94).

12 Katz (2004, p.108).

13 Weinhauer (2017).

14 Social movements are "forms of collective self-organization for the attainment of social recognition and the assertion of rights or existential interests hitherto denied to a group or category of people". These movements engage in "resistance against the threat of a group's or category of people's rights and basis of existence". Social movements are "based on an experience of difference from the political society and involve forms of reflexivity, engage actors in the active interpretation of the present and imagination of the future", Fuchs and Linkenbach (2003, p.1525). 
In the US, against the background of a transnational fear of Bolshevism and a translocal "Red Scare" which evolved even before the US entered the war in 1917, tensions over housing and the labor market generated a severe backlash. In a society already mobilized by the First World War, race and ethnicity became important issues for the activities of localized social movements of working-class origin ${ }^{15}$. Locally rooted ethnic identifications intensified. White fears of the expanding AfroAmerican neighborhoods fed racist attitudes, while fear of Afro- Americans as strikebreakers persisted. These racialized tensions often escalated into open conflict when demobilized soldiers returned from the war. During the years immediately following the First World War, such racialized urban conflicts were not confined to the USA but also became visible in the United Kingdom ${ }^{16}$. What was typical for these seaport riots were competition over jobs and housing but also the spread of rumors of white women being harassed by non-whites. In the USA, however, we find one unique organizational feature which shaped these riots. A closer look at Chicago can demonstrate this.

During the First World War, many Afro-Americans in the United States migrated from the southern states into the industrial cities of the North. Chicago was one of these cities. Until 1914 it had been shaped by transnational migration which then morphed into translocal migration from that point onwards. Chicago's economy encompassed many mass production industries (meat, iron and steel, railroad) and was dominated by big companies Pullman (railroad); Armour and Swift (stockyards), and US Steel. Chicago's Afro-American population more than doubled between 1910 and 1920, with 90\% of this new influx living in the Black Belt of South Side Chicago, from where they had to commute to their jobs. In some meatpacking plants 60-70 percent of the workforce consisted of Afro-Americans ${ }^{17}$.

Initiated by booming meat sales during the Great War, from 1916 the Chicago stockyards saw a rising number of rank-and-file work stoppages ${ }^{18}$. In 1919 in Chicago an estimated 250,000 workers were involved in labor disputes during that summer alone. In the "windy city", between July 1st 1919 and March 1st 1921, fifty-eight bombs exploded within the homes of black residents. From $27^{\text {th }}$ July to $2^{\text {nd }}$ August a riot shook the city which left 38 people dead (among them 14 whites) and 537 injured (342 Afro-Americans and 205 whites), and more than thousand homeless. The key incident was the stoning of a black boy whose raft had drifted over an imagined dividing line into a beach section of whites. It was this urban riot of late July and early August 1919, which took place at the same time as a strike in the stockyards, that extinguished all hopes of racial solidarity in the trade unions as well as in the city ${ }^{19}$.

A space and communication-sensitive understanding of violence helps to reinterpret this riot in two ways. First, the locations of racialized violence differed from earlier "border wars" where groups of whites had often simply marched into Afro-American neighborhoods, terrorized and randomly killed some inhabitants ${ }^{20}$. In

\footnotetext{
15 For an overview, see McWhirter (2011).

16 Jenkinson (2009).

17 Cohen (1990, p.38).

18 Halpern (1997).

19 Halpern (1997, p.47).

20 For an overview, see Diamond (2009).
} 
summer 1919, however, there were clashes between whites and Afro-Americans in Afro-American and in white neighborhoods. While one third of the reported clashes happened in the Black Belt, a chain of neighborhoods on the South Side of Chicago, a further two fifths took place in the white neighborhoods near the stockyards, primarily along thoroughfares in these mostly Irish neighborhoods.

Second, if we closely study these acts of collective violence and ask who employed them we gain new insights. The violence was not simply the product of random individual confrontations. On the side of the mostly Irish youth, it was part of a masculine "culture of physical combat" practiced by groups of young, white men ${ }^{21}$. The established narrative has traditionally claimed that much of the violence that whites employed during the riot was practiced by athletic clubs or gangs, primarily Irish. Their attacks were aimed particularly at Afro-Americans walking to and from work $^{22}$. Whites also used cars to block some thoroughfares and then dragged AfroAmerican trolley riders into the streets and beat them.

A closer look, however, reveals that the ill-defined entity "gang" obscures many features which connect these groups to local society and also sets these entities apart from the routine functions of society. As whites imagined their neighborhood threatened by Afro-American migration they set out to defend their turf collectively. They did this through established neighborhood-based institutions. It would be much more precise to term them not gangs but social movements. What most studies ignore is that in Chicago local politics, especially elections to the city council, were influenced by neighborhood-based social movements far more strongly than in other US cities. The space-based and subculturally interwoven organizing principles of these urban social movements were masculinity, race and ethnicity ${ }^{23}$. They were mostly supported by Democratic politicians. Many of these social movements, such as the infamous Ragen's Colts, were based in the Irish neighborhoods of Bridgeport and Canaryville that lay east of the stockyards. To get to work, African-Americans were forced to cross these districts, leaving them vulnerable to attacks.

In Afro-American precincts collective self-defense of their neighborhoods became a defining feature of the Chicago riot $^{24}$. African-American war veterans played an important role in organizing these social movements and their collective actions. When the veterans came back from the war they self-consciously expected, not only to receive more respect but also socio-political change. Instead in many cities they encountered white supremacists re-establishing the former racial order. As Afro-American intellectual W.E.B. Dubois had predicted it in May 1919, when "We return from fighting. We return fighting" 25 . In Chicago these veterans used their networks of fellow war combatants to organize armed counter measures. Members of this militant social movement barricaded streets in their neighborhoods, stopping all traffic and put up sniping posts. Moreover, some Afro-American workers climbed onto hilltops and began firing across railway tracks into white neighborhoods. Whites that passed through the Black Belt were attacked. Newspapers were aware

\footnotetext{
21 Diamond (2009, p.32).

22 Cohen (1990, p.37).

23 Diamond (2009, p.17-54); Abu-Lughod (2007, p.57).

24 Krugler (2015, p.99-130).

25 The Crisis 18, 1 (May 1919, p.14).
} 
of these new organizational tendencies but could only frame them in contemporary terms influenced by mass psychology as they wrote about white fears of "new crowd negroes" ${ }^{26}$. Besides transnational fears and anxieties of Bolshevism imaginaries of threat were also fueled by local rumors on a massive scale. Rumors spread that AfroAmerican railroad workers were smuggling trainloads of firearms into the Black Belt, that more than seventy-five white policemen had been murdered by black gangs, and that white women had been raped by Afro-Americans ${ }^{27}$. These collective actions in post-war Chicago can demonstrate how urban space was culturally re-coded in these years. What many authors called a race riot more adequately should be labeled a spatialized violent confrontation of urban social movements. In this setting it becomes obvious that violence is no sign of anomie but a central element of social order.

In future research it might be rewarding to reinterpret the violence-ridden history of Latin American big cities from a space and communication based perspective. This could be combined with findings which point towards patterns of order created by an "insurgent citizenship" as it has been brilliantly elaborated by James Holston. The combination of both perspectives could avoid interpretations that things since the 1980s may only become worse and that all patterns of order will erode in these cities in the future ${ }^{28}$.

\section{URBAN TERRORISM: VIOLENT COMMUNICATION AND MEMORY}

Among contemporary urban threats terrorism looms large ${ }^{29}$. In the preceding section I have discussed how (mostly) male urban social movements violently appropriated and defended urban space (understood as physical reality and as imagined entity). In this section I would like to discuss the conditions under which urban violence during the 1970s/1980s, particularly terrorism, could be defused. Long before the recent attacks, political violence which was labelled as terrorism was performed in urban settings. Unlike contemporary suicide bomber attacks, this earlier terrorism often had its roots in particular social milieus and social movements. After the end of the Cold War many of these forms of terrorism were eventually pacified and defused. Employing a space-sensitive and communication-oriented perspective, I will, after some terminological and conceptual clarifications, take a closer look at how this change came about. What will hopefully become obvious is that such a question cannot be answered by focusing on single nation states and its cities. Terrorism and the fight against it are influenced by transnational and translocal transfers. Moreover, I would also like to show that terrorist attacks through the imaginative aspects of space, and the modus by which they are remembered, are closely linked.

Terrorism is a disputed term. What one side calls a freedom-fighter may by the other side be labeled a terrorist. In historical studies of terrorism, something of a consensus has recently begun to emerge. On the one hand, these authors define terrorism as a

\footnotetext{
26 Kornweibel (1998, p.43).

27 Ibid., p.42.; see also Krugler (2015, p.129).

28 See Rodgers (2016); Holston (2008).

29 See Graham (2004); Bishop et al. (2012).
} 
specific form of political violence carried out by sub-state groups which plan and execute their politically-motivated violent actions from a semi-legal or illegal milieu against civilians and against state institutions. The choice of victims and the type of terrorist acts are of symbolic importance and are aimed at spreading insecurity and winning sympathy ${ }^{30}$. On the other hand this approach puts the communicative aspects of terrorism at the forefront: terrorism mainly is a pattern of spatial communication. This, however, must not be interpreted in such a way as to imply that the media are to blame for terrorism. Rather the main impulse of this approach is to integrate terrorism into a complex process of space-based communication of different actors. In this setting the multifold entanglements of terrorists with the state and with media societies are highly important.

Among the potential addressees of terrorist communication, the state is of key importance. Although terrorist actions also communicate to sympathizers, supportive milieus or even competing groups, the state in particular is forced to take action against terrorism, as its monopoly of physical violence is challenged. These state (re-)actions, in turn, are integrated into broader social processes of communication and are telling examples of how state actions are socially perceived. The fact that the actions of terrorists are publicly discussed and news of them is spread translocally and transnationally is a consequence of the advent of mass media societies which arose in Western societies during the late nineteenth century (although there were already debates about the power of the media and about how to control it in the early 1800s). Thus, the agenda setting qualities of terrorism are not confined to some news headlines or to merely produce front-page images. Terrorism not only interacts with some media, but with media societies which are not confined by state borders. Media outlets do not only passively transmit information. Rather, they also set agendas by presenting, interpreting and discussing terrorist acts and related state actions. We must recognize, however, that the media at the same time generates follow-up communication. Given the key importance of communication, it can hardly come as a surprise that terrorism is mainly an urban phenomenon.

Although early terrorism occurred after the French revolution it was in the second half of the nineteenth century that (co-incident with the development of mass media societies) the interaction of terrorism, social movements and the state fully developed. Since then five overlapping phases of terrorism can be discerned ${ }^{31}$. In what follows, I will focus on Northern Ireland where terrorist activity (beginning in the mid-1930s and continuing until the 1980s) had a strong anti-colonial focus which arguably define it as part of the "third phase" of terrorist violence. In addition, I will look at Western Germany and thus at the fourth phase of terrorism. It was associated with the New Left, and often closely connected to middle-class social movements which emerged during the manifold cultural and political upheavals ongoing from the 1960s. This phase stretched until the demise of the socialist states in the late 1980s and early 1990s.

First, a highly important pre-condition for the pacification of anti-colonial terrorism in Northern Ireland and of West German left-wing terrorism in the 1990s was the end of the Cold War and of the related binary coding of the (colonial) order of the state

$30 \quad$ Waldmann (1998, p.10 13); Richardson (2006, p.4ff.).

31 For the following, and for details of the periodization, see Schraut and Weinhauer (2014). 
and of society ${ }^{32}$. This opened new options for remembering political violence and its history. The erosion of Cold War related patterns of dichotomy made it possible to think about political problems and their solutions in a fresh way. Second, since the 1990s the perception and anti-terrorist practices of the state changed. In Northern Ireland, the British state and its institutions lost its authority as an almighty colonial ruler. In Western Germany the change in the image of the state was supported by governmental efforts to de-militarize anti-terrorist police interventions and counter insurgency strategies. Moreover, in both countries repressive governmental measures to fight terrorism seemed to have lost credibility. Third, in the highly differentiated media societies of the early 2000s it became more and more problematic for terrorists to transmit one clear political message to the state. This mattered even more as this state, as I have mentioned before, had lost its demonic image. Moreover, transmitting one special message had to face the omnipresent and multilayered social media communication.

Fourth, in Western Germany and in Northern Ireland the dichotomous patterns of communication (them-versus-us: terrorists versus state/society) slowly eroded during the 1990s. Third players (local peace initiatives and victim's organizations) established themselves between the state and society on the one side and the terrorists on the other side. Northern Ireland saw an upswing of peace-building initiatives on the local level. It was here in local urban settings where community and crosscommunity organizations of the victims of terrorism since the early 1990s made themselves better heard. This was especially true if they could raise the support of local government. In Northern Ireland with the erosion of hermetic and supportive militant milieu, the local political conflicts could be put into the perspective of a world-wide anti-colonial struggle and its transnational and translocal symbols. In early 1990s Western Germany, important impulses came from relatives of victims of the Red Army Faction (RAF) and from political liberals. Both initiatives helped establish stable channels of communication between members of the opposing camps. Thus Western Germany witnessed an erosion of the entrenched lack of communication between the state and the left-wing terrorists and their milieus.

Fifth, in the 1990s, the established cultures of memory of terrorism changed ${ }^{33}$. The dichotomous patterns (them vs us) of remembering eroded, as public memories of terrorism multiplied and became dominated by individualized, often non-political narratives which integrated a broad spectrum of victims. In Northern Ireland the very hermetic local cultures of remembrance were overcome. In Germany the publication in the early 2000s of an increasing number of autobiographies was an expression of this pluralisation of memories of terrorism. Such changes in remembering terrorism still await further research. These processes can underline the resonance which the remembrance of 1970/80s terrorism still has today, but can also demonstrate the analytical advantages of seeing terrorist attacks as spatialized acts of communication. This perspective enables us to overcome the strict separation of event and memory ${ }^{34}$. Understood this way the study (of memories) of terrorism could tell us very much about the functioning of society and about the social and cultural challenges of terrorist attacks.

$32 \quad$ See for the following points Weinhauer (2012); Weinhauer and Requate (2012, p.42-47); Schraut and Weinhauer (2014, p.23-25); Pekelder and Weinhauer (2016, p.298ff).

33 See Weinhauer and Requate (2012, p.31ff.).

34 Wagner-Pacifi (2016, p.23). 
Parallel to the aforementioned five changes, in Europe and in the USA the agenda of terrorism research was considerably widened though professional historians and authors from critical terrorism studies ${ }^{35}$. These changes of the late 1990s (thus obviously in place well before 9/11) marked a deep caesura in the system of academic knowledge about terrorism. Established Cold War scholarly narratives about political violence, the (nation) state and related gender codes but also about victims and patterns of memory were questioned. As a consequence today it is possible to consider to what extend the multifaceted urban consumer societies of the twenty first century themselves can produce potential for terrorism. It may be here where an imagined or real lack of sufficient participation in the promises of consumption and mobility or market induced insecurities may function as sources for militant actions. The latest terrorist attacks in French, Belgian and German cities could have been motivated by such factors ${ }^{36}$. Although urban settings may be sources for violence and threat, they also have vast potentials to create change and to positively adapt to new challenges.

Prof. Dr. Klaus Weinhauer Faculty of History, Philosophy and Theology University of Bielefeld, Germany klaus.weinhauer@uni-bielefeld.de

\section{BIBLIOGRAPHY}

Abu-Lughod, J. (2007) Race, Space, and Riots in Chicago, New York, and Los Angeles, Oxford: Oxford University Press.

Bauman, Z. (2014) State of Crisis, Cambridge: Polity.

Bishop, R., Clancey, G. and Phillips, J. (Eds.) (2012) The City as Target, London: Routledge.

Buitrago, C., Petersen, M., Tyrell, P.M., Wehrmann, D. (2016) Introduction: (Geo-)Political Imaginaries in the Americas, Forum for inter-american research, 9, 1, p.4-18.

Castells, M. (2016) A Sociology of Power, Annual Review of Sociology, 42, p.1-19.

Cohen, E. (1990) Making a New Deal. Industrial workers in Chicago, 1919-1939, Cambridge: Cambridge University Press.

Collins, R. (2008) Violence. A micro-sociological theory, Princeton, NJ: Princeton University Press.

Diamond, A.J. (2009) Mean Streets. Chicago youths and the everyday struggle for empowerment in the multiracial city, 1908-1969, Berkeley: University of California Press.

Fuchs, M. and Linkenbach, A. (2003) Social Movements, in Das, V. (Ed.), The Oxford India Companion to Sociology and Social Anthropology, Oxford: Oxford University Press, p.1524-1563.

Graham, S. (Ed.) (2004) Cities, War, and Terrorism. Towards an urban geopolitics, Malden, Mass.: Blackwell.

35 Schraut and Weinhauer (2014, p.23f.).

36 See on potentials of consumer societies Baumann (2014). 
Halpern, R. (1997) Down on the Killing Floors. Black and white workers in Chicago's packinghouses, 1904-1954, Urbana, Ill.: University of Illinois Press.

Holston, J. (2008) Insurgent Citizenship. Disjunctions of democracy and modernity in Brazil, Princeton: Princeton University Press.

Jenkinson, J. (2009) Black 1919. Riots, racism and resistance in imperial Britain, Liverpool: Liverpool University Press.

Katz, J. and Jackson-Jacobs, C. (2004) The Criminologist's Gang, in Sumner, C. (Ed.), The Blackwell Companion to Criminology, Malden, Mass.: Blackwell, p.91-124.

Kornweibel, T. (1998) Seeing Red. Federal campaigns against Black militancy, 1919-1925, Bloomington: Indiana University Press.

Krug, E.G., Mercy, J.A., Dahlberg, L.L., Zwi, A.B. (2002) World Report on Violence and Health, Geneva: World Health Organization.

Krugler, D. (2015) 1919, the Year of Racial Violence. How African Americans fought back, New York: Cambridge University Press.

Lefèbvre, H. (1991) The Production of Space, London: Wiley Blackwell (Orig. French, 1974).

Lefèbvre, H. (2003) The Urban Revolution, Minneapolis \& London: University of Minneapolis Press (Orig. French, 1970).

McWhirter, C. (2011) Red Summer. The summer of 1919 and the awakening of Black America, New York: Henry Holt.

Pekelder, J. and Weinhauer, K. (2016) The Stammheim Trial (1975-77) against the Leadership of Germany's Red Army Faction and its Legacies, in de Graaf, B. and Schmid, A. (Eds.), Terrorists on Trial. A performative perspective, Leiden: Leiden University Press, p.231-309.

Richardson, L. (2006) What Terrorists Want: Understanding the terrorist threat, London: Murray.

Rodgers, D. (2016) Critique of Urban Violence. Bismarckian transformations in Managua, Nicaragua, Theory, Culture, and Society, 33, 7-8, p.85-109.

Rodgers, D. and Jones, G.A. (2009) Youth Violence in Latin America, in Rodgers, D. and Jones, G.A. (Eds.), Youth Violence in Latin America. Gangs and juvenile justice in perspective, New York/Basingstoke: Palgrave Macmillan, p.1-24.

Schraut, S. And Weinhauer, K. (2014) Introduction: Terrorism, Gender and History. State of research, concepts, case studies, Historical Social Research, 39, 3, p.7-45.

Wagner-Pacifi, R. (2016) Reconceptualizing Memory as Event, in Tota, A.L (Ed.), Routledge International Handbook of Memory Studies, London/New York: Routledge, p.22-27.

Waldmann, P. (1998) Terrorismus: Provokationen der Macht, Munich: Gierling.

Weinhauer, K. (2012) Vom antikolonialen Konflikt zum Kampf um Symbole. Räumliche, lokale und transnationale Perspektiven auf den Nordirlandkonflikt (1967-1998), in Weinhauer, K. and Requate, J. (Eds.), Gewalt ohne Ausweg? Terrorismus als Kommunikationsprozess in Europa seit dem 19. Jahrhundert, Frankfurt/New York: Campus, p.177-199.

Weinhauer, K. (2013) Kriminalität in europäischen Hochhaussiedlungen der 1960/80er Jahre. Vergleichende und transnationale Perspektiven, Informationen zur modernen Stadtgeschichte, 1, p.35-47.

Weinhauer, K. (2017) World War One and Urban Societies: Social movements, fears, and spatial order in Hamburg and Chicago (c. 1916-23), in Rinke, S. and Wildt, M. (Eds.), Revolutions and Counter-Revolution. 1917 and its aftermath from a global perspective, Frankfurt/New York: Campus. 
Weinhauer, K. and Ellerbrock, D. (Eds.) (2013) Stadt, Raum und Gewalt seit dem 19. Jahrhundert, Berlin: Informationen zur modernen Stadtgeschichte.

Weinhauer, K. and Requate, J. (2012) Terrorismus als Kommunikationsprozess: Eskalation und Deeskalation politischer Gewalt in Europa seit dem 19. Jahrhundert, in Weinhauer, K. and Requate, J. (Eds.), Gewalt ohne Ausweg? Terrorismus als Kommunikationsprozess in Europa seit dem 19. Jahrhundert, Frankfurt/New York: Campus, 2012, p.11-47.

Wirth, L. (1938) Urbanism as a Way of Life, American Journal of Sociology, 44, 1, p.1-24.

Wood, J.C. (2007) Locating violence. Space and the construction of physical aggression, in Watson, K. (Ed.), Assaulting the past. Placing violence in historical context, Newcastle: Cambridge Scholars, p.20-37. 